\title{
O spotkaniach literatury i komentarza w twórczości Witkacego
}

ABSTRACT. Górska Irena, O spotkaniach literatury $i$ komentarza w twórczości Witkacego [On the encounters of literature and commentary in Witkacy's works]. "Przestrzenie Teorii" 7, Poznań 2007, Adam Mickiewicz University Press, pp. 105-122. ISBN 978-83-232177-2-5. ISSN 16446763.

In Witkacy's works literature and commentary meet one another incessantly. On one pole a phenomenon of dramatising of theoretical texts, e.g. aesthetic sketches is situated, and on the other the trick of playing theory within own, and on the other a trick of playing theory within own dramaturgy. Both these procedures allow the writer to assume different roles, thus various attitudes towards his own and others' theories. They both make it that the boundaries of literature and commentary are blurred. This also happens when Witkacy transfers his activities literally onto the margin [Marginalia filozoficzne komentarza (Philosophical trifles)]. The philosophical discourse played there in various forms (also plastic ones) makes it that the commented text and the commentary achieve equal status. Such a procedure also shows that reading is a performative act, and that the margin is no longer a marginal place.

Wraz z twórczościq Witkacego krytyka na dobre zainstalowata się $w$ swiecie sztuki samej, teoria, autokrytyka $i$ samowiedza staly się nieodtgeznq częściq procesu twórczego [...]

[T. Burek, Rozmyte tradycje]

„Komentować literaturę [...] to nie tylko ją interpretować (dokonywać wykładni sensu), lecz po prostu i przede wszystkim wytwarzać nowy, autonomiczny tekst" 1 - pisze Michał Paweł Markowski. Zatem w takim ujęciu komentarz jawi się jako samodzielny tekst, „którego sens staje się czytelny także poza kontekstem wyznaczonym przez tekst komentowany" 2 . W ten sposób okazuje się on jednym $\mathrm{z}$ wielu tekstów, które domagają się wielu odczytań, z których z kolei żadne nie jest ostateczne. Co więcej; komentarz potraktowany jako autonomiczny tekst, prowokuje powstanie kolejnego komentarza ${ }^{3}$.

Komentowanie przypominałoby więc niekończący się proces „produkowania" literatury, wytwarzania nowych tekstów o innych tekstach, technikach pisarskich, poetykach, twórcach, a w najszerszym rozumieniu komentarzem byłby każdy tekst dodany do innego tekstu (literackie-

${ }^{1}$ M.P. Markow ski, Efekt inskrypcji. Jacques Derrida i literatura, Bydgoszcz 1997, s. 342.

2 Tamże, s. 348.

${ }^{3}$ Zob. M.P. Markowski, Efekt inskrypcji. Jacques Derrida i literatura, s. 348. 
go, filozoficznego, teoretycznoliterackiego itp.) taki, który by ten tekst objaśniał, oceniał, interpretował itp. Jednak takie myślenie o komentarzu nie prowadzi daleko, co najwyżej wiedzie na obszar opisywany przez takie pojęcia, jak intertekstualność, pantekstualizm, siatka śladów, które - najprościej rzecz ujmując - dają się opisać przez jedno z haseł dekonstrukcjonistów głoszących, że nie ma nic poza tekstem.

Warto zatem pojęcie komentarza doprecyzować, ująć w pewne ramy, choćby po to, by następnie - jak chcą zwolennicy dekonstrukcji - te ramy podważyć.

Jednak sprawa nie jest prosta. Komplikuje się już wówczas, gdy rozważać będziemy utwory autotematyczne (np. powieść będącą własną metodologią, jak pisał kiedyś Michał Głowiński4), a przede wszystkim teksty-komentarze, które $\mathrm{z}$ założenia służą rozważaniom o literaturze czy w ogóle szeroko rozumianej twórczości artystycznej, jednakże wdzierają się do nich elementy literackie. Nie będzie zatem przesadą stwierdzenie, że wszelkie rozważania teoretycznoliterackie, artystyczne, estetyczne noszą znamiona literackie, a bywa i tak, że tekst-komentarz zamienia się $\mathrm{w}$ formę stricte literacką albo przybiera formę plastyczną. W roli takiego komentarza mogą wystąpić notatki na marginesie, znaki graficzne, a nawet fotografie. Z całym tym komentarzowym skomplikowaniem mamy do czynienia w twórczości Witkacego

„W formie pisanej komentarz może obejmować cały tekst - podstawa pozostaje wówczas domyślna; może pojawić się jako segment tekstu bądź jako równoległy do tekstu głównego tekst poboczny"5 - pisze Monika Bogdanowska.

W twórczości Witkacego taka typologia jest oczywiście możliwa, ale warto pójść dalej i pokazać, jak kwestie tekstu i komentarza komplikują się u twórcy Szewców. Obok tekstów będących czytelnymi komentarzami do własnej twórczości (takich, jak rozmaite listy, artykuły, przypisy, przedmowy do własnych dzieł itp.), na uwagę w twórczości Witkacego zasługują teksty zbudowane na zasadzie polaryzacji, takie, w których nieustannie dochodzi do przenikania się tekstu zasadniczego i komentarza. Sytuacja ta sprawia, że czasem trudno ustalić, gdzie są granice tych dwóch typów wypowiedzi (tu warto wskazać na obustronną zależność rozważań Witkacego o sztuce zawartych np. w Szkicach estetycznych i w dramaturgii). I wreszcie jeszcze jeden sposób komentowania - budowanie tekstu równoległego do tekstu właściwego. W twórczości zakopiańskiego artysty tę odmianę komentarza reprezentują mało znane Marginalia filozoficzne.

${ }^{4}$ M. Głowiński, Powieść jako metodologia powieści, w: Porządek, chaos, znaczenie, Warszawa 1968.

5 M. Bogdanowska, Komentarz i komentowanie. Zagadnienia konstrukcji tekstu, Katowice 2003, s. 23. 


\section{Dramatyzowanie szkicu estetycznego}

Kilka lat temu M.P. Markowski zadawał pytanie, czy możliwa jest poetyka eseju6. I nawet nie odpowiedź - paradoksalnie - jest tu najbardziej interesująca. Zastanawiające jest to, że próbując udzielić odpowiedzi na tak postawiony problem, autor od rozważań o literaturze ucieka w samą literaturę. Prezentując różne stanowiska wobec eseju, inscenizuje rozmowę. Wprowadza bohaterów - Filozofa, Krytyka, Intymistę którzy kolejno zabierają głos w sprawie eseju właśnie. Gdy już bohaterowie dialogu wypowiedzą swe kwestie, autor konkluduje: „I tak, beznadziejnie, trwają w sporze uważni czytelnicy Montaigne'a: Filozof, Krytyk i Intymista"7. Zatem rozważanie o eseju, komentarz teoretycznoliteracki wiedzie ku literaturze (?), scence teatralnej (?) Granica między rozprawą naukową a literaturą zostaje zniesiona. Tekst o poetyce eseju stanowi rozważanie teoretycznoliterackie, ale jest też tekstem literackim jednocześnie, przyjmuje formę scenki, dramatycznego zdarzenia, które należy „rozegrać”.

Idąc śladem Markowskiego, w kontekście Szkiców estetycznych Stanisława Ignacego Witkiewicza warto zadać analogiczne pytanie: czy możliwa jest poetyka szkicu estetycznego?

Wydaje się, że najwłaściwiej byłoby mówić o różnych odmianach szkicu estetycznego, literackiego, o tym, że każdy szkic powołuje do istnienia swoją odrębną poetykę, bo wpisanie pewnych odmian tej formy wypowiedzi w słownikową definicję byłoby czasem trudne, a czasem wręcz niemożliwe. Wystarczy przyjrzeć się właśnie Szkicom estetycznym autora Szewców, by stwierdzić, że wypowiedzi o sztuce (teatrze, malarstwie) i literaturze przybierają u tego twórcy różnorodne formy (np. dialogu z fikcyjnym rozmówcą, wykładu naukowego, scenki teatralnej, a nawet noszą znamiona gatunków epickich).

Jak zatem zakopiański artysta buduje szkic estetyczny? Jak to się dzieje, że wykład teoretyczny staje się jednocześnie tekstem artystycznym, zalążkiem literatury pięknej? Wydaje się, że Witkacy ma na to co najmniej dwa sposoby.

Przede wszystkim sam twórca przyjmuje różne role i umiejętnie nimi żongluje - raz jest to po prostu rola Witkacego, filozofa i artysty $\mathrm{z}$ Podhala, a innym razem podmiot staje się aktorem odgrywającym rolę wykładowcy, mentora, który tłumaczy słuchaczom własne teorie, jest uczestnikiem rozgrywanych niczym $\mathrm{w}$ teatrze scen dyskusji o sztuce. Ponadto wprowadza Witkacy na własny użytek fikcyjnych rozmówców,

6 M.P. Markowski, Czy możliwa jest poetyka eseju?, w: Poetyka bez granic, red. W. Bolecki, W. Tomasik, Warszawa 1995.

7 Tamże, s. 115. 
powołuje do istnienia widzów i wciąga ich do gry. To oni pozwalają mu „wypłynąć", dzięki nim może (i tak też czasem czyni) okazać swoją irytację spowodowaną brakiem lotności słuchacza $\mathrm{w}$ pojmowaniu malarskich teorii, a wreszcie - również dzięki fikcyjnym dyskutantom - ma szansę zabłysnąć i po raz kolejny, ze zniecierpliwieniem, ale i swobodą znawcy wytłumaczyć, czym jest malarstwo. Warto przy tym zaznaczyć, że w dramaturgii dzieje się dokładnie odwrotnie. Tam Witkacy udaje, że postacie są mądrzejsze od niego, że wiedzą więcej, że rozumieją estetyczne teorie autora Szewców.

Natomiast w Szkicach estetycznych wprowadzenie fikcyjnego rozmówcy zadającego pytania pozwala Witkacemu na przyjęcie roli nauczyciela-mistrza, mentora. Co więcej, dzięki temu zabiegowi, Witkacy pokazuje, że ten, któremu tłumaczy malarskie teorie, nie jest zbyt pojętny:

Dlaczego nie malować tego, co piękne, tylko wszystko wykrzywiać, robić „kuby” i zygzaki bez sensu itd., itd.?

- pyta fikcyjny rozmówca. Witkacy na to:

O Boże! Znowu to okropne pytanie. Trzeba zacząć od początku nudnym głosem: „Malarstwo nie jest odtworzeniem natury, tylko tworzeniem konstrukcji form na ograniczonych płaszczyznach, czyli, że istotą jego jest kompozycja obrazu [...]”'

Wypowiedź ta, szczególnie $\mathrm{z}$ uwagi na poprzedzające ją „O Boże” sugeruje, że jest już wypowiadana któryś raz z kolei i ciągle nie została właściwie zrozumiana. Warto przy tej okazji podkreślić, że już w przedmowie do Szkiców estetycznych Witkacy zapowiada, że są one uzupełnieniem i poszerzeniem kwestii podjętych w poprzedniej jego pracy Nowe formy $w$ malarstwie $i$ wynikające stąd nieporozumienia. Autor szkiców zakłada z góry, że nawet najbardziej uważni czytelnicy jego prac mogli zapomnieć podstawowe definicje pojęć $\mathrm{i}$ dlatego $\mathrm{w}$ swych rozważaniach raz jeszcze do nich powróci. (Mamy tu więc do czynienia z ciekawym zjawiskiem przenikania się fikcji literackiej i życia. W szkicach niepojętny okazuje się fikcyjny odbiorca, ale przecież z przedmowy można wywnioskować, że ogarnąć teorii Witkacego nie mogą też autentyczni czytelnicy jego dzieła $\mathrm{i}$ właśnie $\mathrm{z}$ myślą o nich szkice powstały. Zatem można powiedzieć, że fikcyjni słuchacze - bohaterowie szkiców - są pośrednikami w przekazywaniu poglądów Witkacego realnym odbiorcom).

Okazywanie zniecierpliwienia ze względu na konieczność ponownego tłumaczenia fikcyjnym słuchaczom własnych poglądów na sztukę również sprawia, że oddalamy się od wywodu naukowego, a zbliżamy raczej do scenki rodzajowej lub wyimka np. z powieści. Wyjaśnienia Witkacego-

8 S.I. Witkiewicz, Nowe formy $w$ malarstwie $i$ wynikajqce stad nieporozumienia. Szkice estetyczne, oprac. J. Degler, L. Soḱ́ł, Warszawa 2002, s. 262.

9 Tamże, s. 262. 
-wykładowcy przerywa następnie wypowiedź słuchaczy prelekcji. „Dobrze, dobrze, to wiemy"10. Głos słuchaczy wyrażony w liczbie mnogiej utwierdza nas w przekonaniu, że mamy do czynienia z zainscenizowanym wykładem. Witkacy-mentor wyjaśnia, słuchacze pytają, przytakują. Witkacowski szkic estetyczny poświęcony deformacji w malarstwie zamienia się w scenkę rodzajową, a może w teatralną sytuację możliwą do odegrania na scenie? Po co Witkacy przytacza rozmowy $z$ fikcyjnymi słuchaczami, cytuje ich wypowiedzi, a co więcej, przywołuje również własne słowa? Oczywiście owo cytowanie jest prawdopodobnie cytowaniem fikcyjnym, „cytowaniem” słów - jak możemy przypuszczać - nigdy wcześniej niewypowiedzianych.

Przytaczanie wypowiedzi swoich i cudzych sprawia, że wywód naukowy ulega silnemu zdialogizowaniu, zatem tekst teoretyczny zbliża się przez to do wypowiedzi artystycznej. Witkacy cytuje fikcyjne wypowiedzi, które zaś sugerują istnienie fikcyjnego bohatera - partnera dialogu dla samego autora. Co istotne, odpowiadając na pytanie fikcyjnego rozmówcy, własną wypowiedź też Witkacy przytacza jako cytat. Cytując siebie, udaje, że przywołuje być może podręcznikową formułkę. Czyżby zatem chęć wymazania śladów własnej obecności?

Po wymianie pytań i odpowiedzi przechodzi autor Szkiców estetycznych do formy niemal klasycznego wykładu, na co wskazują takie wyróżniki, jak np: stosowanie liczby mnogiej, zwroty do słuchaczy: „Wyobraźmy sobie"11 "Weźmy dla przykładu"12, a także budowanie uogólnień:

Niektórzy, stając nawet na stanowisku Czystej Formy, uważają "deformację" za coś odwracającego uwagę od formy i zwracającego ją na przedmioty jako takie $[\ldots]^{13}$.

W trosce o jasność wywodu i utrzymanie poprawnie skonstruowanej formy wykładu Witkacy - tak jak słuchacze - zadaje pytania, ale też sam na nie odpowiada, np.

Czym jest „analiza formy”? Czy rozkładaniem skomplikowanych form świata zewnętrznego na kółka i kwadraty, krzywe linie i proste, czy stylizacją, czy może tzw. „uproszczeniem" - nie wiemy i nie dowiemy się prawdopodobnie nigdy'14.

Gdzie indziej Witkacy pyta:

"Ale gdzie jest granica, którą między dziełami sztuki a innymi dziełami rąk ludzkich przeprowadzić trzeba?” - $\mathrm{i}$ odpowiada: „Granicy takiej nie ma [...]"15.

10 Tamże, s. 262.

11 Tamże, s. 268.

12 Tamże, s. 269.

13 Tamże, s. 271.

14 Tamże, s. 238

15 Tamże, s. 275-276. 
Ponadto, by uwiarygodnić naukowy charakter wykładu autor Szewców buduje definicje utrzymane w konwencji naukowej. Posługując się językiem matematyki, tak pisze o podobaniu się:

Musimy jednak, w odniesieniu nie tylko do dzieł sztuki, ale do przedmiotów, rozróżnić podobanie się wprost, czyli że suma elementów przyjemnych jako takich daje wrażenie ogólne przyjemne, i podobanie się perwersyjne, w którym suma elementów jako takich nieprzyjemnych daje jako całość również wrażenie przyjemne ${ }^{16}$.

Wydaje się, że kiedy autor Szewców buduje takie definicje, polemizuje $\mathrm{z}$ innymi teoriami (np. L. Chwistka) podejmuje po prostu rolę Witkacego, jest jego sygnaturą. Natomiast gdy tworzy sytuacje rozmowy z fikcyjnymi uczestnikami dialogu, staje się aktorem, tworzy teatr, w którym rozgrywa własne teorie, stawia pytania, udziela odpowiedzi, oburza się na mało pojętnych słuchaczy.

Taki sposób budowania szkicu estetycznego pozwala stwierdzić, że Witkacy nie chce utrzymać statusu jednorodnej wypowiedzi. Sam przyjmuje różne role - raz jest krytykiem, raz naukowcem, raz bohaterem prezentowanych scenek dialogowych, a jeszcze innym razem zamienia się w literata. Tym samym jego wypowiedź teoretyczna zbliża się do wypowiedzi artystycznej, komentarz, rozważanie o sztuce - zyskuje charakter dzieła literackiego. Dzieje się tak głównie ze względu na silne zdialogizowanie tekstu, ale też $\mathrm{z}$ uwagi na obrazowość i stosowanie metafor. Ciekawe wydaje się też to, że powagę szkicu estetycznego naruszają zabawne niejednokrotnie przykłady przytaczane przez Witkacego jako ilustracja omawianych kwestii. Autor zderza powagę i żart, styl wysoki sąsiaduje $\mathrm{z}$ niskim:

Zmienianie się mody na tle zblazowania, na to zgadzamy się. Ale wyjaśnienie tego rodzaju futurystycznych obrazów, jak to: tam przeszła dama, tu przeleciał piesek, a tam przemknęło auto, i wszystko biednemu artyście tak się w głowie pokiełbasiło, że narysował oko psa na ogonie damy i na odwrót, a wszystko jeszcze wśród szprychów samochodu zmieszanych ze wspomnieniem o starej ciotce i jej ulubionym kocie, jest według nas nieistotne ${ }^{17}$.

Następnie już w tonacji poważnej, powołując się na własną filozofię, mówi Witkacy o tym, czemu artysta musi tworzyć, tłumaczy, czym jest deformacja, wprowadza i wyjaśnia pojęcie „napięcia kierunkowego”, przytacza różne teorie dotyczące zagadnienia deformacji. Tłumaczy kwestię „dziwności” form w sztuce, dokonuje analizy procesu twórczego. Po wyczerpujących wyjaśnieniach tych zagadnień Witkacy podsumowuje:

Każdy, kto nie zechce pozbawiać się istotnego zrozumienia największej ze Sztuk, malarstwa, i postara się przemóc pewne zakorzenione przez naturali-

16 Tamże, s. 221.

17 Tamże, s. 264. 
styczną ideologię narowy, nie będzie już zadawał tych okropnych pytań: „A czemu deformujecie przedmioty?" "A czemu w takim razie na obrazach są postacie?" Oby się to nareszcie stało ${ }^{18}$.

Zatem raz jeszcze powraca w słowach Witkacego-wykładowcy irytacja spowodowana naiwnymi pytaniami słuchaczy, ale i nadzieja, że jego wyjaśnienia położą tym pytaniom kres.

Szkice estetyczne Witkacego stanowią płaszczyznę, na której spotykają się dwa języki: język filozofii Witkacego i literatury i te dwa języki nieustannie się przenikają, wytwarzając rodzaj dramatycznego napięcia między tym, co literackie i nieliterackie. Jeśli wziąć pod uwagę, że „Witkacy uważał rozmowę, dysputę sceniczną za element bardziej dramatyczny niż tak zwane wypadki [...]"19, to można stwierdzić, że Szkice estetyczne też chwilami przeradzają się $w$ rodzaj dysputy, filozoficznej rozmowy dwóch różnych dyskursów i stąd ich dramatyczność.

Dominującą chyba cechą Witkacowskich szkiców jest silne zdialogizowanie. Rozprawa teoretyczna przyjmuje formę wykładu, domaga się słuchacza, Witkacy potrzebuje partnera do dyskusji, kogoś, kto pozwoli mu nie tylko na powtórne zaprezentowanie własnych poglądów, ale też na zilustrowanie wyjaśnianych kwestii przykładami. Dlatego słuchacz owych wykładów, to słuchacz często mało pojętny, nierozumiejący podstawowych spraw, które Witkacy raz jeszcze ze zniecierpliwieniem wyjaśnia.

Takie postępowanie prowadzi w stronę teatru. W roli głównej występuje tu teoria samego Witkacego. Jej rozgrywanie, rozpisywanie na dialogi czy miniscenki, a także przypisywanie własnych poglądów na sztukę fikcyjnym postaciom - wszystko to sprawia, że szkic estetyczny ulega silnej dramatyzacji i teatralizacji, a stąd już bardzo blisko do dramaturgii, która jest kolejną sceną, na której dochodzi do rozegrania teorii ${ }^{20}$.

\section{Dramat komentarza ${ }^{21}$}

Dramaty twórcy teorii Czystej Formy są tym terenem, na którym dochodzi do uruchomienia teorii, rozegrania komentarza, rozpisania go na role. Można powiedzieć, że dramat komentarza dzieje się tu w sensie najbardziej dosłownym.

${ }^{18}$ Tamże, s. 270.

19 K. Puzyna: Witkacy, Warszawa 1999, s. 44.

${ }^{20} \mathrm{Na}$ temat rozgrywania teorii w twórczości Witkacego zob. A. Krajewska: Witkacego inscenizacje tekstualne, „Pamiętnik Literacki” 2002, z. 4.

${ }^{21} \mathrm{Na}$ temat kryzysu komentarza zob.: R. Barthes, Krytyka $i$ prawda, przeł. W. Błońska, w: Wspótczesna teoria badań literackich za granicq. Antologia, t. 2, Kraków 1972. O kryzysie komentarza i dramacie komentatora pisze też M.P. Markowski, Efekt inskrypcji. Jacques Derrida i literatura. 
Bohaterowie dramaturgii przede wszystkim dyskutują, ale dialog, który wiodą, jest przeważnie dyskusją z poglądami samego Witkacego. Bohaterowie rozprawiają o teorii Czystej Formy (np. Tefuan i Spika w Onych), sami są wyznawcami poglądów Witkacego (np. papież Juliusz II z Mq̨twy), znają i przytaczają teorie filozofów (Chwistka, Leibniza, Kretschmera, Bergsona, Freuda i innych), ale teorie te podają nam we własnym przetworzeniu, zatem zawierzenie im byłoby co najmniej niebezpieczne. Co więcej, bohaterowie mają świadomość gry, wiedzą, że należą do świata literatury.

Np. bohater Szewców Sajetan mówi:

Irina Wsiewołodowna - wam Chwistek zabronił być w polskiej literaturze. I dlatego musi się pani błąkać po sztukach bez sensu, stojących poza literaturą, sztukach, których nikt grać nie będzie ${ }^{22}$.

Czasem jednak sprawiają wrażenie, jakby same żyły poza światem fikcji literackiej. Dzieje się tak wówczas, gdy np. Witkacowskie postacie odwołują się do znajomości dzieł innych dramaturgów:

Leon, bohater Matki, mówi:

Tylko nie zaczynajmy jakichś dramatów à la Ibsen [...],

a tytułowa matka:

Cóż jest genialniejszego niż „Sonata widm” Augusta Strindberga?23

Podsumowując, można wysnuć wniosek, że dla Witkacego budulcem dramaturgii jest świat teorii. Jednak świat zbudowany $z$ literatury tylko w jej ramach może się tłumaczyć, dlatego też nie może uzyskać odniesień do rzeczywistości24. Ale czy z Witkacowską teorią nie jest podobnie? Wydaje się, że można wskazać na zależność odwrotną - świat teorii zbudowany jest $\mathrm{z}$ literatury $\mathrm{i}$ to $\mathrm{w}$ znaczeniu dosłownym. Szkic estetyczny zawiera zalążki dzieła literackiego, od teoretycznego wykładu Witkacy prowadzi nas ku literaturze, buduje sceny, dialogi, które mogłyby się znaleźć w powieści lub dramacie. Niektóre szkice rozpoczynają się niczym powieść lub opowiadanie:

Pewien malarz, nie cierpiący jeszcze na nienasycenie formą, ale przyznający, że sztuka naturalistyczna XIX wieku jest śmiertelnie nudna, rzekł kiedyś: „Wszystko dobrze, ale przyznacie sami, że te wasze wszystkie obrazy latwiej jest skopiować niż obrazy Tycjana np. ${ }^{\text {25 }}$

22 S.I. Witkiewicz, Szewcy, w: tegoż, Dramaty, wybór K. Puzyna, Warszawa 1979, s. 384 .

23 S.I. Witkiewicz, Matka, w: tegoż, Dramaty, s. 331-332.

24 Zob. A. Krajewska, Witkacego inscenizacje tekstualne, „Pamiętnik Literacki” 2002, z. 4.

25 S.I. Witkiewicz, Nowe formy $w$ malarstwie $i$ wynikajqce stqd nieporozumienia, s. 243 . 
Teorie głoszone przez Witkacego w Szkicach estetycznych obecne są też w jego dramaturgii, ale tu pole do popisu daje autor swoim bohaterom literackim. Pozwala im mądrzyć się, swobodnie rozprawiać o teorii Czystej Formy, Tajemnicy Istnienia, Jedności w Wielości, a ponadto o teoriach rozmaitych filozofów, pisarzy, naukowców. Co więcej, o poważnych sprawach natury filozoficznej lub filozofach bohaterowie często mówią z lekceważeniem, jakby byli zbyt wielcy, by takie kwestie roztrząsać. Bohater Mqtwy, Bezdeka, mówi:

Jesteśmy ograniczeni, a otacza nas Nieskończoność. Jest to zbyt banalne, żeby o tym mówić ${ }^{26}$.

Natomiast Bałandaszek z Onych w dyskusji ze Spiką powiada:

Stworzyć coś jest rzeczą trudną. Zorganizować upadek - czyż jest coś łatwiejszego? Istnienie samo jest ciągłym upadkiem czegoś. Tylko głowę sobie łamię, czym jest właśnie to. Łatwo jest bredzić à la Bergson ${ }^{27}$.

Sytuacje, w których postacie dramatów twórcy Czystej Formy powołują się na jego teorie estetyczne i filozoficzne pozwalają wysnuć wniosek, że Witkacy próbuje się ukryć za wypowiedziami pozornie nie swoimi - wkłada je w usta postaci. Choć jest obecny w cytowanych przez postaci słowach, to funkcjonuje on jako ktoś $\mathrm{z}$ zewnątrz, jeden $\mathrm{z}$ wielu filozofów, pisarzy, na których częstokroć powołują się jego bohaterowie. Zatem autor Szewców tylko „udaje”, że nie jest obecny w dziele. Podobnie zresztą ślady swej obecności jako podmiotu zaciera, gdy przywołuje w Szkicach estetycznych własne słowa $\mathrm{w}$ formie cytatu. To cytat właśnie staje się zasłoną, za którą ukrywa się autor.

Podmiot szkiców jest podmiotem ruchomym, zmiennym, niejednoznacznym; jest literatem, teoretykiem, uczestnikiem dyskusji, raz postacią fikcyjną, a raz sygnaturą samego Witkacego - autora teorii Czystej Formy. Gdy autor cytuje własne słowa (nawet, jeśli przyjąć, że jest to paradoksalnie - cytat słów nigdy niewypowiedzianych), bierze tę wypowiedź w cudzysłów, gdy zaś podmiot jest sygnaturą samego Witkacego, nie używa cudzysłowu ${ }^{28}$.

Gdyby przyciąć nieco wybrany Witkacowski szkic estetyczny i wydobyć z niego tylko kilka kolejnych partii dialogowych, okazałoby się, że jesteśmy niezwykle blisko dramaturgii. Warto przyjrzeć się zatem wybranym przykładom ze szkicu $O$ tzw. „deformacji” ksztaltów świata zewnętrznego i z dramatów:

${ }^{26}$ S.I. Witkiewicz, Mqtwa, w: tegoż, Dramaty, s. 212.

27 S.I. Witkiewicz, Oni, w: tegoż, Dramaty, s. 34.

28 Zob. S.I. Witkiewicz, Nowe formy $w$ malarstwie $i$ wynikajqce stad nieporozumienia, szczególnie szkic: O tzw. „deformacji” ksztaltów świata zewnętrznego. 
- Dlaczego nie malować tego, co piękne, tylko wszystko wykrzywiać, robić „kuby" i zygzaki bez sensu itd., itd.?"

- O Boże! Znowu to okropne pytanie. Trzeba zacząć od początku nudnym głosem: „Malarstwo nie jest odtworzeniem natury, tylko tworzeniem konstrukcji form na ograniczonych płaszczyznach, czyli, że istotą jego jest kompozycja obrazu. Części tej kompozycji muszą różnić się od siebie i dlatego są różnobarwne. Harmonia lub konieczny dysonans (dysharmonia) kolorystyczny jest tym, co nadaje istotne życie kompozycji i potęguje jej jednolitość, bo jedność w wielości...”.

- „Dobrze, dobrze, to wiemy. Ale czemu nie malować w takim razie oderwanych form, do niczego niepodobnych? Czemu na obrazach są postacie ludzkie różnej płci, zwierzęta, rośliny, wody i góry?"29

- Malarz nie jest przecie matematykiem ani maszyną do rachowania. Jest osobnikiem tego rodzaju, że w samej jego pracy, której wynik może być tak oderwany, jak jakieś matematyczne twierdzenie, potrzebny mu jest cały jego świat uczuć i wyobrażeń, w której to sferze załamuje się uczucie jedności jego „ja”, jego metafizyczne uczucie, a jednak mimo to wyraża się jedynie w Czystej Formie, tj. konstrukcji form i harmonii kolorów.

- Och metafizyka! Rzecz tak dziś niemodna. Wprawdzie Bergson pisze o sympatii czy czymś podobnym, ale... A te kierunkowe napięcia, masy, osie, konstrukcje - to przecież elektryczne potencjały, mechanika, dynamika i geometria. Wszystko, tylko nie Sztuka. [...] Jeśli to wszystko do uczucia nie przemawia i wymaga takich objaśnień, to widocznie nic nie jest warte ${ }^{30}$.

A oto rozważania o malarstwie bohaterów Witkacowskich dramatów: Plazmonik tłumaczy Klaudestynie teorię malarską stworzoną przez jego ojca:

\section{PLAZMONIK:}

Rozumie pani, chodzi o wyrażenie metafizycznej dziwności Istnienia w konstrukcjach czysto formalnych bezpośrednio przez samą harmonię barw, ujętych w pewne kompozycje... ${ }^{31}$

\section{KLAUDESTYNA:}

Ja maluję cuda natury z punktu widzenia owadów, żab, i innych małych stworzeń. Nie maluję ich jednak tak, jak one są, tylko w oświetleniu mego metafizycznego spojrzenia duchowego $[. . .]^{32}$

\section{Inna bohaterka Bezimiennego dzieła, Róża, o malarstwie mówi tak:}

Malarstwo jest zawsze jednak tylko, w najlepszym razie, zdeformowaną naturą - niczym więcej. Te wszystkie próby umuzykalnienia malarstwa to jedno wielkie kłamstwo - od przedmiotów nie uwolnicie się nigdy ${ }^{33}$.

29 Tamże, s. 262.

30 Tamże, s. 262-263.

31 S.I. Witkiewic z, Bezimienne dzieto, w: tegoż, Dramaty, s. 150.

32 Tamże, s. 150.

33 Tamże, s. 176. 
Wydaje się, że przytoczone przykłady swobodnie można by zamienić miejscami. Komentarz zbliża się do tekstu literackiego, a utwór literacki zyskuje cechy komentarza. Wypowiedzi Witkacego (te fikcyjne i te autentyczne) oraz słowa jego fikcyjnych rozmówców przytaczane w Szkicach estetycznych $\mathrm{z}$ pewnością mogłyby pełnić funkcję dramatycznego dialogu, zaś wypowiedzi bohaterów dramaturgii z powodzeniem służyłyby ilustracji tez teoretycznych roztrząsanych przez Witkacego w Szkicach estetycznych.

Łatwo dostrzec, że granice literatury i wypowiedzi o literaturze z powodzeniem znosi autor teorii Czystej Formy. Próba oddzielenia literatury i komentarza nie może się powieść. Nie udaje się bowiem oddzielić autorskich sądów teoretycznych od praktyki twórczej. Komentarz i tekst literacki przenikają się. Dramaty noszą znamię teorii Witkacego, a teksty krytyczne, estetyczne napiętnowane są literaturą. Wychodząc od komentarza, zmierzamy do tekstu, podejmując próbę interpretacji, wracamy do uwag teoretycznych. Zostajemy schwytani w pułapkę, z której w najlepszym razie - możemy uciec jedynie na margines.

\section{Zdarzenie na marginesie}

Zaryzykujmy stwierdzenie, że Witkacy nie jest ani literatem, ani teoretykiem, ani też filozofem. Jest jednym, drugim i trzecim równocześnie. Witkacy-dramaturg i powieściopisarz nie może - albo nie chce uwolnić siebie i swoich literackich bohaterów od własnej teorii i filozofii sztuki, a Witkacy-teoretyk nieustannie tkwi w literaturze. Granica między twórczością artystyczną a teorią okazuje się nieprzekraczalna. Twórca wiedzie nas na manowce - czytając dramaturgię i powieści zakopiańskiego artysty, jesteśmy zmuszani do przywoływania Witkacowskich teorii dotyczących sztuki, religii, filozofii, a czytając szkice estetyczne, powracamy do literatury. Czasem Witkacy prowadzi nas na margines (jak najbardziej dosłownie) i pokazuje, że to też dobre miejsce dla uprawiania sztuki i że wbrew wszystkiemu margines wcale nie musi być miejscem marginalnym.

Marginalia filozoficzne to nieznana dotąd forma aktywności artystycznej Stanisława Ignacego Witkiewicza. Witkacy czyta rozprawy filozoficzne Alfreda Tarskiego, Tadeusza Kotarbińskiego, Romana Ingardena, Joachima Matallmanna oraz wielu innych filozofów i na gorąco z nimi dyskutuje. Slady tej dyskusji utrwala na marginesie w formie tekstów bądź rysunków. Na styku tekstu komentowanego i marginesu dochodzi do zderzenia filozofii i sztuki. Jak zauważa Paweł Polit, sporządzanie notatek na marginesie staje się dla autora Nowych form $w$ malarstwie 
„okazją do przeprowadzenia swoistej inwentaryzacji pojęć i problemów filozoficznych", ale marginalia są też "obszarem gry całkowicie bezinteresownej, kojarzącej się z dziedziną doświadczenia estetycznego" 34 . Margines, z pozoru niewiele znaczące, drugorzędne miejsce, staje się sceną, na której prowadzi się spór, demonstruje własną lekturę, jednorazową interpretację. Czytanie prowokuje do pisania. Lektura zamienia się w dyskurs. Nanoszone na margines glosy są polemiką z czytanymi tekstami, ale jednocześnie prezentacją własnych interpretacji tychże tekstów i własnych poglądów. Margines staje się miejscem demonstrowania sądów i opinii, co więcej, daje impuls do dalszych polemik, prowokuje do dyskursu z dyskursem.

Witkacy jest wytrawnym graczem - do owej gry filozofii ze sztuką wprowadza siebie samego, przyjmuje rolę współautora komentowanego tekstu, o czym świadczy chociażby fakt, że tworzy nowy tekst nie tylko na marginesie, ale również poprzez nadanie własnego tytułu komentowanym rozważaniom Alfreda Tarskiego. Zamiast Pojęcia prawdy $w$ językach nauk dedukcyjnych, wprowadza Witkacy, nowy, alternatywny tytuł Unitas multiplex, „wypowiadający podstawowe w myśleniu Witkiewicza pojęcie jedności w wielości"35.

Marginalia Witkacego można określić mianem dzieła niegotowego, utworu-fragmentu, sylwy współczesnej ${ }^{36}$, jest to bowiem tekst, który ciągle się staje, tekst w ruchu, który nieustannie prowokuje do dalszych przekształceń i nowych odczytań. Teksty zapisane na marginesie mają różny status i charakter - czasem są wyrazem akceptacji dla danego stanowiska, czasem je podważają, lekceważą, a nawet kpią $\mathrm{z}$ tez przedstawionych w komentowanych tekstach, często mają też żartobliwy charakter.

Zdarza się, że są to dłuższe uwagi wyrażone np. jednym zdaniem, jak chociażby taka utrzymana w żartobliwym tonie: „To parszywy zawód nam zrobiłeś, Kochany Alfredzie" - te słowa pisze Witkacy w odniesieniu do takiej oto deklaracji Alfreda Tarskiego: „Nie zamierzam natomiast kusić się o nadanie metanauce charakteru ściśle sformalizowanej nauki dedukcyjnej" [s. 21] ${ }^{37}$. Czasem marginalia mają formę wykrzyknienia,

34 P. Polit, Fragment, rama, seria. O wizualnych aspektach marginaliów filozoficznych Witkacego, w: Stanisław Ignacy Witkiewicz. Marginalia filozoficzne, Warszawa 2004, (numeru strony nie podano).

35 Tamże.

36 Zob. R. Nycz, Sylwy wspótczesne, Kraków 1996.

37 Numery stron w nawiasach dotyczą tekstów A. Tarskiego, Pojęcie prawdy w językach nauk dedukcyjnych oraz T. Kotarbińskiego, Elementy teorii poznania, logiki formalnej $i$ metodologii nauk zamieszczonych w książce: Stanisław Ignacy Witkiewicz. Marginalia filozoficzne, Warszawa 2004.

\section{Irena Górska | 116}


niekoniecznie cenzuralnego - „Dobre! Bycze!” [s. 172], „W ogóle cholera”, [s. 471].

Zdarza się też, że Witkacy podważa autorytet autora komentowanego tekstu, gdy np. stwierdzenie T. Kotarbińskiego:, „...bo przestrzeń chwilowa jest trójwymiarową, euklidesową", komentuje z lekceważeniem: „To już Descartes powiedział" lub po prostu, gdy Kotarbiński stwierdza, że „trwania muszą [...] być czterowymiarowe”, Witkacy pyta: Skąd on to wziął? [s. 465]. Gdy autor Elementów teorii poznania, logiki formalnej $i$ metodologii nauk pisze: „Warto jednak zauważyć...”, Witkiewicz na marginesie zapisuje: „Czy warto?” [s. 439], a na górnym marginesie komentowanej strony notuje: „Poco to u cholery? Zawracanie łba i tyla!!” [s. 439], albo: „Takie powiedzonka coś znaczą w fizyce a w ontologii są bzdurami" [s. 470]. Zdarza się również, że Witkacy przyznaje się do kłopotów ze zrozumieniem czytanych rozważań filozoficznych, wyznając: „To potworne ale już trochę rozumiem” [s. 471]. Gdy Kotarbiński rozważa sytuację prawdziwości rachunku zdań w warunkach, gdy poprzednik jest fałszywy i następnik fałszywy, Witkacy stwierdza wprost: „wtedy też nie ma żadnej implikacji tylko dwie bzdury obok siebie" [s. 167].

Witkiewiczowskie marginalia przybierają różnorodne formy: tekstu, rysunku, rozmaitych znaków graficznych, które tworzą swoistą ramę dla komentowanych dzieł. Pojęcie ramy nie pojawia się tu przypadkowo. Okazuje się, że właśnie komentarz może przybierać formę ramy i to w znaczeniu najbardziej dosłownym, co pokazują praktyki Witkacego. Rama staje się tu tekstem i ramą obrazu jednocześnie. Każe komentowany tekst percypować tak, jak percypuje się obraz, ale też wpływa znacząco na sposób lektury.

Tekst staje się obrazem, dla którego rama nie jest już jednak elementem zdobniczym, ale osiąga status równorzędny z tym, co otacza. Bez ramy lektura tekstu jest uboższa, zaś czytanie samej ramy - wbrew przytoczonej wcześniej opinii M. P. Markowskiego o komentarzu jako tekście autonomicznym - okazuje się niemożliwe. Trudno wyobrazić sobie lekturę Witkacowskich marginaliów jako samodzielnego tekstu, co potwierdzają przytoczone uprzednio przykłady. Wydaje się, że tylko równoległe czytanie tekstu komentowanego i komentarza ma sens, bo tylko wtedy komentarz jest czytelnym przekazem. Jest on zapisem swoistej rozmowy $\mathrm{z}$ dziełem rozgrywanej "na gorąco" w momencie lektury. Można powiedzieć, że komentarz jest zdarzeniem, czymś, co jest wymuszane przez proces lektury. Czytanie zamienia się w pisanie, tzn., że słowa nie służą tu opisywaniu czegokolwiek, lecz są jednoznaczne $\mathrm{z}$ działaniem $^{38}$. Nasuwa się tu również pytanie o to, jakie znaczenie ma forma

${ }^{38}$ Zob. J.L. Austin, Jak dziatać stowami, w: tegoż, Mówienie i poznawanie, przel. B. Chwedeńczuk, Warszawa 1993. 
zapisu. Czy dałoby się komentarze Witkacowskie czytać jako tekst ciągły? Co wyznaczałoby kolejność zapisu poszczególnych uwag? Rozstrzygnięcie tej kwestii okazuje się niemożliwe, gdyż konkretne uwagi autora Nowych form $w$ malarstwie odnoszą się do konkretnych fragmentów komentowanych tekstów. Zatem tekst komentowany i komentarz należałoby czytać równolegle. Komentarze Witkiewicza żyją tylko wraz z tekstem komentowanym, nim się żywią i w jego kontekście mają sens. Rama z marginesowych notatek pełni rolę tekstu pobocznego i niczym didaskalia w dramacie podpowiada, jak „wykonać” tekst główny. Didaskalia pełnią rolę dramatycznego komentarza, opisują działanie, czyli dramat, są narracją o dramatycznych zdarzeniach, komentarzem, który „podpowiada”, jak grać, mają więc moc performatywów, nakazują działanie, choć czasem wcale niejednoznacznie. Tak jak Derridiański parergon rama oddziela wnętrze od zewnętrza, ale jednocześnie do wnętrza wnika i odsyła na zewnątrz. Parerga staje się tekstem, który każe odnieść się do kolejnych tekstów. I nie jest to rama wyłącznie pozorna wynikająca z materialnego nośnika tekstu, bo „sposobem istnienia tekstu jest nie substancjalność, a interpretacja" 39 .

Stworzone przez Witkacego marginalia uprzestrzenniają komentowane teksty, nadają im wizualny charakter. Komentarz tworzy ramę dla "wewnętrznego" tekstu, ale jednocześnie rama ta raczej łączy niż dzieli. Znaki graficzne rozrywają ową granicę, tworzą w niej prześwity, które umożliwiają - jak powiedziałby Wojciech Kalaga - osmozę obu tekstów, dialog między wnętrzem i zewnętrzem ${ }^{40}$.

Wizualne zderzenie tekstu podstawowego i "pobocznego" tworzy tekst-obraz, który przypomina kolaż wychodzący z ram. Rozmaite strzał$\mathrm{ki}$, podkreślenia, zakreślenia wiodą $\mathrm{w}$ dwóch kierunkach - od tekstu komentowanego na margines i odwrotnie - $\mathrm{z}$ marginesu do tekstu komentowanego. Całość staje się mozaiką słów, znaków, rysunków, które wzajemnie się warunkują. Aspekt wizualny, plastyczny jest nie do przecenienia. Niemożliwe okazuje się przeczytanie wyłącznie samych marginaliów jako samodzielnego tekstu, ale nie udaje się też lektura komentowanego dzieła, gdyż rozmaite znaki graficzne „zmuszają” do obejmowania wzrokiem również marginesu.

Komentowany tekst wraz z komentarzem tworzy nową jakość. To już nie dzieło literackie, filozoficzne opatrzone komentarzem, lecz zdarzenie, rozgrywka, próba sił między tym, co wewnątrz a tym, co na zewnątrz. Komentarz rozbija od środka strukturę tekstu filozoficznego, podważa jego sensy, każe przyjąć czytelnikowi inny punkt widzenia i stale zderzać

${ }^{39}$ W. Kalaga, Mgławice dyskursu. Podmiot, tekst, interpretacja, Kraków 2001, s. 237-238.

${ }^{40}$ Zob. W. Kalaga, Mgtawice dyskursu. Podmiot, tekst, interpretacja, s. 214. 
komentowane dzieło $\mathrm{z}$ komentarzem. Zamiast pojęcia dzieła pojawia się pojęcie procesu, „dziania się”, czegoś, co nieustannie się wydarza. Lektura wytwarza jakąś sytuację, zmienia ją, działa niczym performatyw. $\mathrm{W}$ takim ujęciu estetykę dzieła zastępuje estetyka zdarzenia. Ten rodzaj gry Witkacego z filozofią umacnia przekonanie, że dzieło nigdy nie jest czymś jednorazowo i jednoznacznie określonym. Lektura musi być doświadczeniem. „Dzieła nie są dostępne w raz na zawsze obowiązującej określoności swej obiektywnej egzystencji. W zetknięciu z nimi doświadczenie estetyczne, nawet przy wielkim znawstwie, potrafi wciąż się odświeżać, ponieważ bezpośredniego kontaktu zmysłowego nie zastąpi żadna pamięć, żadna teoria czy sprawozdanie"41. Jak zauważa Rüdiger Bubner jedność dzieła powstaje w procesie obcowania $\mathrm{z}$ nim, doświadczania lektury i jest osiągana wciąż na nowo ${ }^{42}$. Bliski temu myśleniu o tekście jest również Wojciech Kalaga, który stwierdza, że istnienie tekstu rozumianego jako kategoria ontologiczna zależy od bezpośredniego doświadczania owego tekstu przez odbiorcę. Tekst bowiem nie jest stałym, raz danym zespołem znaczeń, lecz nieustannym procesem, „holograficzną mgławicą w przestrzeni semiotycznej". Tak pojmowany tekst nie może być ograniczony żadną ramą narzuconą mu przez materialność. Ma jedynie zamazany kontur, który roztapia się $\mathrm{w}$ tekstualnej przestrzeni ${ }^{43}$.

Sposób uprawiania filozoficznej lektury przez Witkacego można określić jako akt performatywny. Czytanie bowiem okazuje się równocześnie działaniem. Na marginesie czytanego tekstu dochodzi do inscenizacji. Marginalia okazują się rodzajem sprawozdania $\mathrm{z}$ bezpośredniego spotkania $\mathrm{z}$ tekstem; $\mathrm{z}$ jednego konkretnego spotkania, gdyż każde kolejne dałoby zapewne odmienny rezultat.

Czytelnik nigdy „nie wchodzi dwa razy” do tego samego tekstu - nie dlatego jednak, a przynajmniej nie w pierwszym rzędzie dlatego, że sam się zmienia, a dlatego, że tekstowa mgławica podlega nieprzerwanej transformacji powodowanej pojawieniem się nowych relacji dyskursywnych i przesunięciom istniejących relacji względem siebie i względem różnych obszarów przestrzeni semiotycznej ${ }^{44}$.

Sposób czytania, jaki uprawia Witkacy, przypomina metodę dekonstrukcji. Parafrazując Derridę, warto zapytać o to, co pozostaje z rzeczy, gdy zostaje ona przeczytana. Otóż, można odpowiedzieć: notatka, rysunek na marginesie. Lektura okazuje się jednorazowym zdarzeniem, de-

41 R. Bubner, Doświadczenie estetyczne, przel. K. Krzemieniowa, Warszawa 2005, s. 70 .

42 Zob. R. Bubner, Doswiadczenie estetyczne, s. 75.

43 Zob. W. Kalaga, Mglawice dyskursu. Podmiot, tekst, interpretacja, s. 240.

44 W. Kalaga, Mgtawice dyskursu. Podmiot, tekst, interpretacja, s. 228. 
monstracją, rozgrywką między komentowanym tekstem a własnymi teoriami, między wydobyciem i zakwestionowaniem sensów. Zapisywany przez Witkacego margines staje się kontekstem dla kolejnych odczytań komentowanych tekstów A. Tarskiego, T. Kotarbińskiego, R. Ingardena, J. Matallmanna i wielu innych. Zaś kontekst ten w nieskończoność można rozszerzać, co pozwoli "wyłonić się dalszym złożonościom badanego dzieła"45. Można chyba uznać, że na marginesie dzieł filozoficznych Witkacy uprawia małe dekonstrukcje będące ,jednorazowymi, niepowtarzalnymi «działaniami» [performances] [...], które performatywnie interweniują w polu [swej] «analizy» lub «lektury»"46.

Rama, którą tworzy z własnych uwag i komentarzy Witkacy pozwala - mówiąc językiem dekonstrukcji - podejść do komentowanego tekstu, ale akt ten jest jednocześnie podważeniem ramy. Krawędź ta nie ujmuje bowiem tekstu jako jednostki totalnej, wręcz przeciwnie, pokazuje niemożność ogarnięcia go jako całości. Wypadnie zgodzić się zarówno z Rolandem Barthes'em jak i Jacquesem Derridą, że tekstu nie da się wtłoczyć w żadne ramy i traktować go jako zamkniętą, zreifikowaną jednostkę dyskursu. Marginalia filozoficzne Witkacego - jak zauważa Paweł Polit - dowodzą nieustannego przenikania się sztuki i filozofii, ale ta stała oscylacja rozbija wewnętrzną jedność dzieła, do której dążył twórca teorii Czystej Formy47.

W przypadku twórczości Witkacego badanie wybranych przykładów form o charakterze teoretycznym, estetycznym, krytycznym, które noszą jednocześnie znamiona dzieła literackiego, wydaje się nie lada wyzwaniem. Wyzwaniem tym większym, że - jak dostrzega Anna Łebkowska „strefa pogranicza sama w sobie jest niestabilna i coraz to inne, nowe obszary na swoje terytorium zagarnia, obszary w dodatku także silnie drążone przez ruchy tektoniczne zmieniające ich krajobraz. Ponadto miejsca skrzyżowania przyciągają siłą atrakcji, ale zarazem stają się zarzewiem sporów, co zresztą także wzmaga ich powab"48.

W kontekście rozważań o formach komentarza w twórczości Witkacego wypadnie zgodzić się ze stwierdzeniem Clifforda Geertza, że rozważania filozoficzne przybierają coraz częściej formę krytyki literackiej, dywagacje naukowe prezentowane są „pod płaszczykiem beletrystycznych

45 J. Culler, Dekonstrukcja i jej konsekwencje dla badań naukowych, w: Dekonstrukcja $w$ badaniach literackich, red. R. Nycz. Archiwum przekładów „Pamiętnika literackiego" pod red. M. Głowińskiego, Gdańsk 2000, s. 371.

${ }^{46}$ A. Burzyńska, Dekonstrukcja i interpretacja, Kraków 2001, s. 54.

47 Zob. P. Polit, Fragment, rama, seria. O wizualnych aspektach marginaliów filozoficznych Witkacego.

${ }^{48}$ A. Łebkow sk a, Między teoriami a fikcjq literackq, Krak6w 2001, s. 19. 
morceaux [...], barokowe fantazje przedstawiane ze śmiertelną powagą jako obserwacje empiryczne [...], prace historyczne złożone z równań i tablic lub z zeznań sądowych [...], reportaże, co brzmią jak zwierzenia poufne [...], przypowieści udające opis etnograficzny [...], traktaty teoretyczne pomyślane jako pamiętnik podróży [...], spór ideologiczny ujęty w formę dociekań z zakresu historiografii [...], badanie epistemologiczne skonstruowane jak traktat polityczny [...], polemika metodologiczna ukształtowana na wzór wspomnień osobistych [...]. Bardzo chyba znamienny dla naszych czasów jest utwór Nabokova Blady ogień, ów obiekt niemożliwy, na który składają się poezja i powiesć, uczone przypisy i obrazowanie rodem $\mathrm{z}$ kliniki. Jeszcze trochę, a ukaże się teoria kwantowa wierszem lub biografia w zapisie algebraicznym"49.

Wypowiedź Geertza wskazuje na niezwykle znamienne dla dzisiejszej literatury przenikanie się różnych typów wypowiedzi literackich i nieliterackich, a właściwie nie tyle jest to przenikanie się, bo nie chodzi tylko o wplatanie literatury do komentarza, ale też o to, że komentarz teoretycznoliteracki często "ubierany” jest w formę literacką. Odczytywanie tekstów-komentarzy staje się dla czytelnika swoistą grą w rozpoznania konwencji, odszyfrowywanie ról, ustalanie, co traktować serio, a co tylko jako autorską mistyfikację.

Witkacy, który prowadzi grę z tekstem i odbiorcą, który miesza style, znosi granice między żartem a powagą, między realnym twórcą, podmiotem a podejmowanymi i porzucanymi nieustannie różnymi rolami, który wreszcie sprawia, że światy literatury i teorii przenikają się, sytuuje się na granicy modernizmu i postmodernizmu.

Waga, jaką przywiązywał autor Nowych form w malarstwie do koncepcji „czystej formy", i - co za tym idzie - wyłączność jego zainteresowań wewnętrzną problematyką twórczości [...] może stanowić jeden ze wskaźników modernistycznej postawy pisarza ${ }^{50}$.

Za tą postawą przemawiałby też fakt, że autor Szewców uważa sztukę za dziedzinę twórczości, która zdąża do własnych, autonomicznych celów estetycznych. Ponadto Witkacy poszukuje tego, co swoiste dla poszczególnych sztuk (muzyka, malarstwo, literatura), okazuje skłonność do eksperymentów, dąży do oryginalności, a ponadto skłonny jest do programowości, co przejawia się $w$ potrzebie tworzenia teoretycznych uza-

$49 \mathrm{C}$. Geertz, O gatunkach zmqconych, w: Postmodernizm. Antologia przekładów pod red. R. Nycza, Kraków 1998, s. 215.

50 B. Danek-Wojnowska, Stanistaw Ignacy Witkiewicz a modernizm. Kształtowanie idei katastroficznych, Wrocław 1976, s. 83. 
sadnień działań twórczych (stąd liczne komentarze do twórczości). Inna sprawa, że Witkacowska teoria rozmija się z praktyką. Może na szczęście dla tej twórczości?

Z drugiej jednak strony Witkacy znosi granicę między sztuką elitarną a popularną, o którą to troszczyli się moderniści, wprowadza formy hybrydyczne, miesza style, zderza sprzeczne kategorie estetyczne, eksponuje grę z konwencjami, a przy tym caly czas zachowuje ironiczny dystans wobec własnej twórczości. Wszystko to sprawia, że można nazwać go postmodernistą. Jednak - jak zauważa Ewa Wąchocka - „Pokrewieństwo technik artystycznych z chwytami postmodernizmu, pozorna latwość zaadaptowania przyjętych na jego potrzeby pojęć i określeń nie świadczą jeszcze, że Witkacego można nazwać postmodernistą, przed czym przestrzegał Włodzimierz Bolecki" 51 . A może porzucić trudne próby ustalenia czy Witkacy był modernistą czy postmodernistą i przystać na propozycję Grzegorza Sinki, który nazywa Witkacego po prostu wielkim klasykiem i dodaje: „A cechą klasyka jest to, że w różnych okolicznościach, przy różnych okazjach sięga się po różne jego dzieła"52.

Lech Sokół proponuje, aby zamiast badać, czy Witkacy jest awangardowy czy nieawangardowy, przestarzały czy nowoczesny, raczej zwrócić uwagę na to, że jego dramaturgia ,jest wyjątkowo szczęśliwą próbą pogodzenia czegoś bardzo ważnego $\mathrm{w}$ tradycji europejskiej - $\mathrm{z}$ chwytami awangardowymi. Tak więc nie jest to awangarda przylepiona do tradycji ani tradycja, która się czepia awangardy, tylko - coś niepowtarzalnego, jedynego w swoim rodzaju"53. I tak też niepowtarzalna i jedyna w swoim rodzaju okazuje się Witkacowska teoria, której nigdy nie udało się przełożyć na praktykę.

51 E. Wą chock a, Witkacy na przełomie stuleci, „Pamiętnik Literacki” 2002, z. 4, s. 254.

52 Witkacego portret wielokrotny. Dyskusja z udziałem J. Deglera, J. Klossowicza, K. Puzyny, G. Sinki i L. Sokoła, w: K. Puzyna, Witkacy, s. 208.

${ }^{63}$ Tamże, s. 214. 